\title{
FAKTOR- FAKTOR YANG BEHUBUNGAN DENGAN KEJADIAN DBD DI WILAYAH KERJA PUSKESMAS AMBARAWA KABUPATEN PRINGSEWU PROVINSI LAMPUNG 2017
}

\author{
Diatika Pratiwi ${ }^{1)}$
}

\begin{abstract}
Abstrak
Kejadian DBD di Wilayah Kerja Puskesmas Ambarawa Kabupaten Pringsewu tahun 2017 sebanyak 24 kasus $(20,0 \%)$, kepadatan jentik 65 rumah $(54,2 \%)$, suhu seluruh rumah $>30 \mathrm{oC}$ yaitu 120 rumah. $(100,0 \%)$, kelembaban rumah sebagian besar $40-70 \%, 114$ rumah $(95.0 \%)$, tipe container kuat terbanyak 117 rumah (97.5\%), container di dalam rumah sebagian bésar 95 rumah ( $79,2 \%)$, sebagian besar responden melakukan perilaku PSN yaitu sebanyak 62 orang $(51,7 \%)$ dan sebagian besar responden memiliki pengetahuan baik yaitu 66 orang $(55,0 \%)$.

Bagi puskesmas harus lebih berperan aktif dalam pemberantasan penyakit DBD melalui upaya pemberantasan perkembangbiakan nyamuk Aedes aegypti dengan melakukan 3M khususnya pada saluran penampungan air dengan cara menyikat pangkal dan dinding secara teratur.
\end{abstract}

Kata Kunci : DBD, Aedes aegypti

${ }^{1)}$ Alumni Prodi D4 Kesehatan Lingkungan Poltekkes Tanjungkarang

\section{PENDAHULUAN}

DBD adalah penyakit endemis yang dilaporkan selalu ada setiap tahun. Pada tahun 2015 jumlah penderita DBD yang dilaporkan sebanyak 129.650 kasus dengan jumlah kematian sebanyak 1.071 orang $(I R=50,75$ per 100.000 penduduk dan $\mathrm{CFR}=0,83 \%$ ). Dibandingkan tahun 2014 dengan kasus sebanyak 100.347 serta IR 39,80 terjadi peningkatan kasus pada tahun 2015. Target Renstra Kementerian Kesehatan untuk angka kesakitan DBD tahun 2015 sebesar $<49$ per 100.000 penduduk, dengan demikian Indonesia belum mencapai target Renstra 2015. (Profil Kesehatan Indonesia, 2015:188).

Faktor yang mempengaruhi peningkatan kasus dan Kejadian Luar Biasa (KLB) DBD yaitu, pertumbuhan penduduk global dan urbanisasi yang tidak terencana dan terkontrol, kurangnya peran sertamasyarakat dalam pengendalian DBD, terutama pada kegiatan PSN, serta faktor lingkungan seperti iklim, infrastruktur penyediaan air bersih yang tidak memadai dan kebersihan lingkungan, pekarangan yang tidak bersih, seperti bak mandi yang jarang dikuras, pot bunga, genangan air di berbagai tempat, ban bekas, batok kelapa, potongan bambu, drum, kalengkaleng bekas serta botol-botol yang dapat menampung air dalam jangka waktu yang lama (Depkes RI, 2011).

\section{METODE}

Penelitian dengan rancangan kasus kontrol ini dilakukan pada bulan Mei - Juni 2017 di wilayah kerja Puskesmas Ambarawa, Kabupaten Pringsewu. Sampel kasus adalah penduduk atau orang yang di diagnosis sebagai penderita DBD dan tercatat berdasarkan data medik di Puskesmas Ambarawa, berdasarkan perhitungan diperoleh 24 orang. Sampel kontrol sebanyak 96 orang yang diambil oleh peneliti adalah penduduk atau orang yang bukan penderita DBD yang merupakan rumah tetangga kasus yang bertempat tinggal dalam radius 100 meter dari tempat tinggal kasus, serta tidak dilakukan matching atau pencocokan. 
HASIL

\section{Kejadian DBD}

Pada penelitian ini mengunakan perbandingan $1: 4$ dimana kasus berjumlah 24 sedangkan kontrol berjumlah 96, sehingga keseluruhan berjumlah 120 responden.

Tabel 1. Distribusi Kejadian DBD

\begin{tabular}{lcc}
\hline Kejadian DBD & Frekuensi & $\begin{array}{c}\text { Persentase } \\
(\%)\end{array}$ \\
\hline Kasus & 24 & 20,0 \\
Kontrol & 96 & 80,0 \\
Jumlah & 120 & 100 \\
\hline
\end{tabular}

\section{Keberadaan Jentik}

Hasil mendapati $54,2 \%$ kontainer terdapat jentik nyamuk dan $45,8 \%$ tidak dijumpai jentik nyamuk. Pada kelompok kasus yang terdapat jentik sebanyak $83,3 \%$, pada kelompok kontrol yang terdapat jentik sebanyak $46,9 \%$. Hasil uji statistik dengan chi square diperoleh ( $p$-value $=$ $0,003)<\alpha=0,05$ yang berarti bahwa ada hubungan kejadian DBD dengan keberadaan jentik. OR $=5,667$ yang berarti bahwa rumah responden yang terdapat jentik nyamuk lebih berisiko 5,667 kali mengalami DBD dibandingkan dengan responden yang tidak terdapat jentik nyamuk di rumahnya.

Tabel 2. Hubungan kejadian DBD dan keberadaan jentik

\begin{tabular}{lcccccc}
\hline Keberadaan jentik & \multicolumn{2}{c}{ Kasus } & \multicolumn{2}{c}{ Kontrol } & \multirow{2}{*}{ P-value } & OR \\
\cline { 2 - 4 } & $\mathrm{n}$ & $\%$ & $\mathrm{n}$ & $\%$ & & $95 \% \mathrm{CI}$ \\
\hline Ada & 20 & 83,3 & 45 & 46,9 & & \multirow{2}{*}{ (16,667 } \\
Tidak ada & 4 & 16,7 & 51 & 53,1 & 0,003 & $(1,802-17,824)$ \\
Jumlah & 24 & 100 & 96 & 100 & & \\
\hline
\end{tabular}

\section{Jenis Kontainer}

Hasil observasi yang dilakukan, jenis kontainer yang terdapat di tempat tinggal responden di kelompokkan menjadi kuat dan tidak kuat. $94,2 \%$ jenis kontainer tidak berwarna terang dan $5,8 \%$ lainnya berwarna terang. Pada kelompok kasus dengan jenis kontainer yang tidak berwarna terang sebanyak $87,5 \%$, pada kelompok kontrol dengan jenis kontainer yang tidak berwarna terang sebanyak $95,8 \%$. Hasil uji statistik dengan chi square diperoleh $p$-value $=0,142>\alpha=0,05$ yang berarti bahwa tidak ada hubungan kejadian DBD dengan jenis kontainer.

Tabel 3. Hubungan kejadian DBD dan jenis kontainer

\begin{tabular}{|c|c|c|c|c|c|c|}
\hline \multirow{2}{*}{ Jenis Kontainer } & \multicolumn{2}{|c|}{ Kasus } & \multicolumn{2}{|c|}{ Kontrol } & \multirow{2}{*}{$\begin{array}{c}P- \\
\text { value }\end{array}$} & \multirow{2}{*}{$\begin{array}{c}\text { OR } \\
95 \% \mathrm{CI}\end{array}$} \\
\hline & $\mathrm{n}$ & $\%$ & in & $\%$ & & \\
\hline Tidak Berwarna Terang & 21 & 87,5 & 92 & 95,8 & \multirow{3}{*}{0,142} & \multirow{3}{*}{$\begin{array}{c}0,304 \\
(0,063-1,463\end{array}$} \\
\hline Berwarna Terang & 3 & 12,5 & 4 & 4,2 & & \\
\hline Jumlah & 24 & 100 & 96 & 100 & & \\
\hline
\end{tabular}

\section{Letak Kontainer}

Hasil observasi yang dilakukan, maka letak kontainer yang terdapat di tempattinggal responden di kelompokkan berdasarkan tempat peletakkannya. Terdapat $20,8 \%$ terletak di dalam rumah dan $79,2 \%$ terletak di luar rumah. Pada kelompok kasus dengan letak kontainer di dalam rumah sebanyak $41,7 \%$, sedangkan dengan kontainer di luar rumah sebanyak $58,3 \%$. Pada kelompok kontrol dengan letak kontainer di dalam rumah sebanyak $15,6 \%$, sedangkan dengan kontainer di luar rumah sebanyak $84,4 \%$. Hasil uji statistik dengan chi square diperoleh $p$-value $=0,010<\alpha=0,05$ yang berarti bahwa ada hubungan kejadian DBD dengan letak kontainer, kemudian diperolch $\mathrm{OR}=3,857$ yang berarti bahwa letak kontainer di dalam rumah mempuntyai risiko sebanyak 3,857 kali menyebabkan kejadian DBD dibandingkan dengan kontainer yang letaknya di luar rumah. 
Tabel 4. Hubungan kejadian DBD dan letak kontainer

\begin{tabular}{|c|c|c|c|c|c|c|}
\hline \multirow[t]{2}{*}{ Letak Kontainer } & \multicolumn{2}{|c|}{ Kasus } & \multicolumn{2}{|c|}{ Kontrol } & \multirow{2}{*}{$\begin{array}{c}P- \\
\text { value }\end{array}$} & \multirow{2}{*}{$\begin{array}{c}\text { OR } \\
95 \% \mathrm{CI}\end{array}$} \\
\hline & $\mathrm{n}$ & $\%$ & $\mathrm{n}$ & $\%$ & & \\
\hline Luar rumah & 10 & 41,7 & 15 & 15,6 & \multirow{3}{*}{0,010} & \multirow{3}{*}{$\begin{array}{c}3,857 \\
(1,446-10,286\end{array}$} \\
\hline Dalam rumah & 14 & 58,3 & 81 & 84,4 & & \\
\hline Jumlah & 24 & 100 & 96 & 100 & & \\
\hline
\end{tabular}

\section{Prilaku PSN}

Berkaitan dengan perilaku PSN, 51,7\% responden melakukan PSN dan 48,3\% tidak melakukan PSN. Pada kelompok kasus yang melakukan prilaku PSN sebanyak 7 orang $(29,2 \%)$, sedangkan yang tidak melakukan prilaku PSN sebanyak 17 orang (70,8\%). Pada kelompok kontrol yang melakukan prilaku PSN sebanyak 55 orang $(57,5 \%)$, sedangkan yang tidak melakukan prilaku PSN sebanyak 41 orang $(42,7 \%)$.

Hasil uji statistik dengan chi square diperoleh $p$-value $=0,021<\alpha=0,05$ yang berarti bahwa ada hubungan kejadian DBD dengan prilaku PSN, OR $=3,285$ yang berarti bahwa responden yang tidak melakukan prilaku PSN mempuntai risiko sebanyak 3,285 kali mengalami kejadian DBD dibandingkan dengan responden yang melakukan prilaku PSN.

Tabel 5. Hubungan kejadian DBD dan perilaku PSN

\begin{tabular}{lcccccc}
\hline \multirow{2}{*}{ Perilaku PSN } & \multicolumn{2}{c}{ Kasus } & \multicolumn{2}{c}{ Kontrol } & P- & OR \\
\cline { 2 - 5 } & $\mathrm{n}$ & $\%$ & $\mathrm{n}$ & $\%$ & value & $95 \% \mathrm{CI}$ \\
\hline T. Melakukan & 17 & 70,8 & 41 & 42,7 & & 3,285 \\
Melakukan & 7 & 29,2 & 55 & 57,3 & 0,021 & $(1,237-8,528)$ \\
Jumlah & 24 & 100 & 96 & 100 & & \multirow{2}{*}{ J } \\
\hline
\end{tabular}

\section{Pengetahuan}

Pengetahuan responden baik sebanyak $34,2 \%$ dan kurang baik $65,8 \%$. Diketahui bahwa pada kelompok kasus yang memiliki pengetahuan baik sebanyak $25 \%$, sedangkan yang mempunyai pengetahun kurang baik scbanyak $75 \%$. Pada kclompok kontrol yang memiliki pengetahuan baik sebanyak $62,5 \%$, sedangkan yang mempunyai pengetahun kurang baik sebanyak $37,5 \%$. Hasil uji statistik dengan chi square diperoleh $p$-value $=0,003<\alpha=0,05$ yang berarti bahwa ada hubungan kejadian DBD dengan pengetahuan, diperoleh $\mathrm{OR}=$ 7,526 yang berarti bahwa responden yang mempunyai pengetahun kurang baik mempunyai risiko scbanyak 7,526 kali mengalami kejadian DBD dibandingkan dengan responden yang mempunyai pengetahun baik.

Tabel 6. Hubungan kejadian DBD dan perilaku PSN

\begin{tabular}{|c|c|c|c|c|c|c|}
\hline \multirow{2}{*}{ Pengetahuan } & \multicolumn{2}{|c|}{ Kasus } & \multicolumn{2}{|c|}{ Kontrol } & \multirow{2}{*}{$\begin{array}{c}P- \\
\text { value }\end{array}$} & \multirow{2}{*}{$\begin{array}{c}\text { OR } \\
95 \% \mathrm{Cl}\end{array}$} \\
\hline & $\mathrm{n}$ & $\%$ & $\mathrm{n}$ & $\%$ & & \\
\hline Baik & 2 & 25,0 & 57 & 62,5 & & \\
\hline Kurang baik & 22 & 75,0 & 39 & 37,5 & 0,003 & $\begin{array}{c}1,526 \\
(1.673-33.857)\end{array}$ \\
\hline Jumlah & 24 & 100 & 96 & 100 & & \\
\hline
\end{tabular}

\section{PEMBAHASAN}

\section{Kejadian DBD}

Menurut World Health Organization (2012:1) Demam Berdarah Dengue (dengue Haemoragick Fever / DHF) ditandai dengan empat gejala klinis utama : demam tinggi, fenomena hemoragi, sering dengan hepatomegali dan pada kasus berat disertai tanda-tanda kegagalan sirkulasi. Syok ini 
disebut syndrom syock dengue (DSS) dan sering menyebabkan fatal.

Penyebaran DBD dipengaruhi oleh peran serta masyarakat. Peran serta masyarakat akan muncul apabila sudah ada perubahan perilaku masyarakat dari tidak melakukan menjadi melakukan untuk perilaku positif dan dari melakukan menjadi tidak melakukan untuk perilaku negatif. Sedangkan perubahan perilaku terjadi setelah mengalami proses yang dimulai dari mengetahui (know), memahami (comprehension), aplikasi (aplication), analisa (analysis), sintesis (syntesis) dan evaluasi (evaluation) (Ipa, 2009).

Menurut Budiarto (2003), Pada prinsipnya kejadian penyakit yang digambarkan sebagai segitiga epidemiologi menggambarkan hubungan tiga komponen penyakit yaitu pejamu (host), penyebab (agent), lingkungan (environment). Agent penyebab penyakit demam berdarah dengue adalah virus Dengue Terdapat empat serotipe dari virus Dengue yang semuanya dapat menyebabkan DBD. Virus ini ditularkan melalui gigitan nyamuk Ae. aegypti. Nyamuk betina terinfeksi melalui pengisapan darah dari orang yang sakit. Tempat perindukan Ae. aegypti dapat dibedakan atas tempat perindukan sementara, permanen, dan alamiah. Tempat perindukan sementara terdiri dari berbagai macam tempat penampungan air (TPA) yang dapat menampung genangan air bersih. Tempat perindukan permanen adalah TPA untuk keperluan rumah tangga dan tempat perindukan alamiah berupa genangan air pada pohon. Cara yang saat ini dianggap tepat untuk mengendalikan penyebaran DBD adalah dengan mengendalikan populasi dan penyebaran vektor, yaitu dengan $3 \mathrm{M}$ : menguras bak mandi, menutup TPA, dan mengubur barang bekas. (World Health Organization-The Virus, 2012).

Host atau Penjamu adalah manusia atau organisme yang rentan oleh pengaruh agent dalam penelitian ini yang diteliti dari faktor penjamu adalah (umur, pendidikan, pekerjaan, motivasi, pengetahuan dan sikap).

Dalam penyebaran penyakit DBD faktor lingkungan seperti tempat penampungan air scbagai perindukan nyamuk Aedes aegypti aegypti, ketinggihan tempat suatu daerah mempengaruhi perkembangbiakan nyamuk dan virus, curah hujan serta kebersihan lingkungan.

Di Indonesia puncak penularan DBD terjadi pada awal tahun, yaitu bulan Januari-April, karena berkaitan dengan puncak musim hujan dan berdampak pada munculnya tempat perindukan atau breeding places dari nyamuk Aedes aegypti aegypti. Oleh karena itu, Pemerintah telah meluncurkan Gerakan 1 Rumah 1 Jumantik sejak tahun lalu yang merupakan bagian dari upaya pemberantasan sarang nyamuk (PSN) melalui 3M Plus yaitu, Menguras, Menutup, dan Mendaur ulang, ditambah Mengindari gigitan nyamuk. Gerakan ini dimaksudkan untuk mengajak setiap keluarga dan seluruh masyarakat agar mencegah munculnya perindukan nyamuk $A e$. aegypti di rumah atau di tempat kerja masingmasing, dengan cara membasmi setiap jentik yang ditemukan dan meniadakan genangan air baik di luar maupun di dalam rumah atau gedung. Hal ini dikarenakan anggota keluarga lebih dapat menjangkau tempat-tempat yang menjadi sarang nyamuk di lingkungannya.

Kejadian kasus DBD di wilayah kerja Puskesmas Ambarawa tersebar di tujuh desa yaitu Desa Ambarawa, Ambarawa Barat, Ambarawa Timur, Jati Agung, Kresnomulyo, Margodadi dan Sumber Agung. Jumlah penderita atau responden yang terkena DBD di Desa Ambarawa yaitu sebanyak 24 penderita.

Penderita penyakit DBD berdasarkan umur di wilayah Kecamatan Ambarawa terjadi pada kelompok umur diatas 40 tahun. Sedangkan usia terendah responden yang terkena DBD terjadi pada balita berumur 3 tahun. Dari uraian tersebut, menunjukkan bahwa di sekitar wilayah kerja Puskesmas Ambarawa perlu diadakannya penyuluhan mengenai pencegahan dan pengobatan DBD schingga kedepannya kejadian DBD dapat diturunkan atau dihilangkan.

\section{Keberadaan Jentik}

Hasil penelitian diketahui bahwa pada responden kasus yang terdapat jentik sebanyak $83,3 \%$, pada responden kontrol yang terdapat jentik sebanyak $46,9 \%$. Hasil uji statistik dengan chi square diperoleh $p$-vaue $=0,003$ yang berarti bahwa ada hubungan kejadian DBD dengan keberadaan jetik. Kemudian diperoleh $\mathrm{OR}=5,667$ yang berarti bahwa responden yang terdapat jentik nyamuk berisiko 5,667 kali mengalami DBD dibandingkan dengan responden yang tidak terdapat jentik nyamuk. 
Keadaan ini sesuai dengan penelitian Ririh Y. dan Anny V (2005) di Surabaya yang menyebutkan bahwa terdapat hubungan yang bermakna antara kejadian DBD dengan suhu rumah responden karna keberadaan jentik nyamuk termasuk kategori tinggi sehingga mempunyai risiko transmisi nyamuk yang cukup tinggi untuk terjadi penularan penyakit DBD.

Menurut Depkes RI (2005) survey jentik nyamuk Aedes aegypti dilakukan dengan cara sebagai berikut: semua tempat atau bejana yang dapat menjadi tempat perkembangbiakan nyamuk Aedes aegyptidiperiksa (dengan mata telanjang) untuk mengetahui ada tidaknya jentik; untuk memeriksa TPA yang berukuran besar, seperti: bak mandi, tempayan, drum dan bak penampungan airlainnya. Jika pada pandangan (penglihatan) pertama tidak menemukan jentik, tunggu kira-kira 1 menit untuk memastikan bahwa benar jentik tidak ada; untuk memeriksa tempat-tempat perkembangbiakan yang kecil, seperti: vas bunga atau pot tanaman air atau botol yang airnya keruh, sering kali airnya perlu dipindahkan ketempat lain serta untuk memeriksa jentik di tempat yang agak gelap, atau airnya keruh, biasanya digunakan senter.

Jentik memerlukan empat tahap perkembangan. Jangka waktu perkembangan jentik tergantung pada suhu, ketersediaan makanan, dan keberadaan jentik dalam sebuah kontainer. Dalam kondisi optimal, waktu yang dibutuhkan dari telur menetas hingga menjadi nyamuk dewasa adalah tujuh hari,termasuk dua hari dalam masa pupa. Sedangkan pada suhu rendah, dibutuhkan waktu beberapa minggu.

Kesenangan tempat perindukan nyamuk biasanya berupa genangan air yang tertampung disuatu tempat atau bejana. Nyamuk Aedes aegypti tidak dapat berkembangbiak di genangan air yang langsung bersentuhan dengan tanah. Genangannya yang disukai sebagai tempat perindukan nyamuk ini. Survei yang telah dilakukan di beberapa kota di Indonesia menunjukkan bahwa tempat perindukan yang paling potensial adalah TPA yang digunakan sehari-hari seperti drum, tempayan, bak mandi, bak WC, ember dan sejenisnya. Tempat perindukan tambahan adalah disebut non-TPA, seperti tempat minuman hewan, vas bunga, perangkap semut dan lain-lainnya, sedangkan TPA alamiah seperti lubang pohon, lubang batu, pelepah daun, tempurung kelapa, kulit kerang, pangkal pohon pisang, potongan bambu dan lainlainnya. Nyamuk Aedes aegypti lebih tertarik untuk meletakkan telurnya pada TPA berair yang berwarna gelap, paling menyukai warna hitam, terbuka lebar, dan terutama yang terletak di tempat-tempat terlindung sinar matahari langsung.

Tempat perindukan nyamuk Aedes aegypti yaitu tempat di mana nyamuk Aedes aegypti meletakkan telurnya terdapat di dalam rumah (indoor) maupun di luar rumah (outdoor). Tempat perindukan yang ada di dalam rumah yang paling utama adalah tempat-tempat penampungan air seperti bak mandi, bak air WC, tandon air minum, tempayan, gentong tanah liat, gentong plastik, ember, drum, vas tanaman hias, perangkap semut dan lain-lain. Sedangkan tempat perindukan yang ada di luar rumah (halaman) seperti drum, kaleng bekas, botol bekas ban bekas, pot bekas, pot tanaman hias yang terisi oleh air hujan, tandon air minum dan lain-lain.

Kebiasaan istirahat nyamuk Aedes aegypti lebih banyak di dalam rumah pada benda-benda yang bergantung, berwarna gelap, dan di tempat-tempat lain yang terlindung. Di tempattempat tersebut nyamuk menunggu proses pematangan telur. Setelah beristirahat dan proses pematangan telur selesai, nyamuk betina akan meletakan telurnya di dinding tempat perkembangbiakannya, sedikit di atas permukaan air. Pada umumnya telur akan menetas menjadi jentik dalam waktu \pm 2 hari setelah telur terendam air. Setiap kali bertelur nyamuk betina dapat mengeluarkan telur sebanyak 100 butir. Telur tersebut dapat bertahan sampai berbulan-bulan bila berada di tempat kering dengan suhu $-2^{\circ} \mathrm{C}$ sampai $42^{\circ} \mathrm{C}$, dan bila di tempat tersebut tergenang air atau kelembabannya tinggi maka telur dapat menetas lebih cepat.

Menurut Iranurilla (2010), Pengendalian nyamuk dapat dilakukan dengan menggunakan beberapa metode yang tepat antara lain:

a. Pengendalian lingkungan

Pengendalian dilakukan dengan cara mengelola lingkungan yaitu memodifikasi atau manipulasi lingkungan agar tidak cocok (kurang baik) untuk perkembangan vektor. Modifikasi lingkungan merupakan cara paling aman dan tidak merusak keseimbangan alam 
dan tidak mencemari lingkungan, tetapi harus dilakukan terus menerus. Sebagai contoh, pengaturan sistem irigasi, penimbunan tempattempat yang dapat menampung air dan tempattempat pembuangan sampah, pengaliran air yang menggenang menjadi kering, pengubahan rawa menjadi sawah dan pengubahan hutan menjadi tempat pemukiman. Manipulasi lingkungan adalah cara yang berkaitan dengan pembersihan atau pemeliharaan sarana fisik yang telah ada supaya tidak terbentuk tempattempat perindukan atau tempat istirahat serangga. Sebagai contoh, membersihkan tanaman air yang mengapung di danau seperti ganggang dan lumut yang dapat menyulitkan perkembangan Anopheles sundaicus, mengatur kadar garam di lagoon yang dapat menekan populasi Anopheles subpictus dan Anopheles sundaicus, melestarikan kehidupan tanaman bakau yang membatasi tempat perindukan Anopheles sundaicus, membuang atau mencabut tumbuh-tumbuhan air yang tumbuh di kolam atau rawa yang dapat menekan populasi Mansonia spp, melancarkan air dalam got yang tersumbat agar tidak menjadi tempat perindukan Culex.

b. Biologi

Pelihara ikan pemakan jentik nyamuk seperti ikan adu / ikan cupang dan bakteri thuringiensis H-14 yang akan merusak usus setelah memakan bakteri atau menggunakan ikan kepala timah sebagai predator pemakan jentik nyamuk.

\section{c. Kimia}

Nyamuk Aedes aegypti sp dapat diberantas dengan fogging (pengasapan) racun serangga yang dipergunakan sehari-hari untuk nyamuk dewasa, melakukan Pembersihan Sarang Nyamuk Demam Berdarah Dengue (PSN DBD), melakukan Larvasida dengan cara membubuhkan bubuk pembunuh jentik (abate) ditempat yang sulit dikuras atau didaerah yang sulit air dan bisa juga dengan mengunakan obat nyamuk (bakar, gosok (repellent) dil) untuk mencegah gigitan nyamuk.

d. Fisik

Pemasangan kawat kasa di rumah, Pencahayaan dan ventilasi memadai jangan membiasakan menggantung pakaian di dalam rumah, karena akan menjadi tempat peristirahatan nyamuk, dan pergunakan kelambu pada saat tidur untuk mencegah gigitan nyamuk Aedes aegypti aegvpti.

\section{Jenis Kontainer}

Hasil penelitian diketahui bahwa pada kelompok kasus dengan jenis kontainer yang tidak kuat sebanyak 3 orang $(12,5 \%)$. Pada kelompok kontrol dengan $100 \%$ kontainer adalah jenis yang kuat. Hasil uji statistik dengan chi square diperoleh $p$-value $=0,142$ yang berarti bahwa tidak ada hubungan kejadian DBD dengan jenis kontainer. Keadaan ini tidak sesuai dengan penelitian Ririh Y. dan Anny V (2005) di Surabaya yang menyebutkan bahwa ada hubungan yang bermakna antara kejadian DBD dengan jenis kontainer. Jenis tempat perkembangbiakan nyamuk Aedes aegypti dapat dikelompokkan sebagai berikut : tempat penampungan air (TPA) untuk keperluan sehari-hari, seperti drum, tangki reservoir, tempayan, bak mandi/wc, dan ember. Tempat penampungan air bukan untuk keperluan sehari-hari seperti (Non TPA) seperti : tempat minum burung, vas bunga, perangkap semut dan barang-barang bekas (ban, kaleng, botol, plastik dan lain-lain). Tempat penampungan air alamiah seperti : lubang pohon, lubang batu, pelepah daun, tempurung kelapa, pelepah pisang dan potongan bambu. Setelah beristirahat dan proses pematangan telur selesai, nyamuk betina akan meletakan telurnya di dinding tempat perkembangbiakannya, sedikit di atas permukaan air.

Sebagai upaya untuk menghindari pertumbuhan jentik nyamuk, sebaiknya jenis kontainer yang digunakan responden harus berbahan yang kuat dan berwarna terang. Menutup tempat penampungan air juga dapat mencegah nyamuk dapat berkembang biar di penampungan air tersebut. Menguras dan menyikat dinding tempat penampungan air atau kontainer air minimal 1 kali seminggu serta menaburkan bubuk abate ke dalam penampungan air yang mempunyai kapasitas besar dan tempat yang jauh dari sumber air bersih. menyingkirkan tempat tempat yang berpotensial menyebabkan nyamuk bertelur seperti ban bekas, kaleng bekas, dan gentong air yang tergenang air hujan juga perlu dilakukan oleh responden.

\section{Letak Kontainer}

Hasil penelitian diketahui bahwa pada kelompok kasus dengan letak kontainer di dalam rumah sebanyak 10 orang $(41,7 \%)$, 
sedangkan dengan kontainer di luar rumah sebanyak 14 orang $(58,3 \%)$. Pada kelompok kontrol dengan letak kontainer di dalam rumah sebanyak 15 orang $(15,6 \%)$, sedangkan dengan kontainer di luar rumah sebanyak 81 orang $(84,4 \%)$.

Hasil uji statistik dengan chi square diperoleh $p$-value $=0,010$ yang berarti bahwa ada hubungan kejadian DBD dengan letak container, diperoleh $\mathrm{OR}=3,857$ yang berarti bahwa letak kontainer di dalam rumah mempuntyai risiko sebanyak 3,857 kali menyebabkan kejadian DBD dibandingkan dengan kontainer yang letaknya di luar rumah.

Keadaan ini sesuai dengan penelitian Ririh Y. dan Anny V (2005) di Surabaya yang menyebutkan bahwa terdapat hubungan yang bermakna antara kejadian DBD dengan letak kontainer.

Jenis kontainer yang digunakan responden harus berbahan yang kuat dan berwarna terang untuk menghindari pertumbuhan jentik nyamuk. Menutup tempat penampungan air juga dapat mencegah nyamuk dapat berkembang biar di penampungan air tersebut. Menguras kontainer air juga harus dilakukan minimal 1 kali seminggu serta menggunakan bubuk abate ke dalam penampungan air bila terdapat jentik nyamuk. menyingkirkan tempat tempat yang berpotensial menyebabkan nyamuk bertelur seperti ban bekas, kaleng bekas, dan gentong air yang tergenang air hujan juga perlu dilakukan oleh responden.

\section{Prilaku PSN}

Hasil penelitian diketahui bahwa pada kelompok kasus yang melakukan prilaku PSN sebanyak 7 orang $(29,2 \%)$, sedangkan yang tidak melakukan prilaku PSN sebanyak 17 orang $(70,8 \%)$. Pada kelompok kontrol yang melakukan prilaku PSN sebanyak 55 orang $(57,5 \%)$, sedangkan yang tidak melakukan prilaku PSN sebanyak 41 orang $(42,7 \%)$.

Hasil uji statistik dengan chi square diperoleh $p$-value $=0,021$ yang berarti bahwa ada hubungan kejadian DBD dengan prilaku PSN di wilayah kerja Puskesmas Ambarawa, Kabupaten Pringsewu pada tahun 2017, kemudian diperoleh $\mathrm{OR}=3,825$ yang berarti bahwa responden yang tidak melakukan prilaku PSN mempuntyai risiko sebanyak 3,825 kali mengalami kejadian DBD dibandingkan dengan responden yang melakukan prilaku PSN.
Secara kimia PSN DBD biasanya dilakukan dengan menaburkan bubuk abate pada tempattempat penampungan air, akan tetapi bubuk abate belum bisa didapatkan secara mudah sehingga responden belum dapat melakukan PSN DBD secara kimia. Hal ini tentunya juga dapat menambah risiko bagi jentik nyamuk Aedes aegypti untuk hidup dan berkembangbiak pada tempat-tempat penampungan air. PSN DBD secara biologi yang dilakukan dengan cara memelihara ikan pada tempat-tempat penampungan air juga belum dilakukan responden. Sebenarnya cara ini adalah cara alamiah dan cara yang cukup efektif untuk membasmi jentik Aedes aegypti aegypti, akan tetapi responden enggan melaksanakannya karena ikan yang dipeliharaakan menyebabkan bau amis pada tempat penampungan air responden.

Keadaan ini sesuai dengan penelitian Widagdo et.al (2008) di Kelurahan Srondol Wetan Semarang menunjukkan bahwa terdapat hubungan yang bermakna antara PSN 3-M Plus di bak mandi, ember dan gentong plastik dengan jumlah jentik ditempat penampungan air tersebut. Menurut (Depkes RI, 2005) cara yang dianggap paling tepat untuk memberantas vektor (Aedes aegypti aegypti) adalah dengan PSN DBD. Apabila kegiatan PSN DBD dilakukan oleh seluruh masyarakat secara terus menerus dan berkesinambungan maka keberadaan jentik Ae. aegypti dapat dibasmi, sehingga risiko penularan DBD dapat dikurangi. Untuk itu maka perlu dilakukan kegiatan-kegiatan di dalam masyarakat seperti kegiatan bulan bakti gerakan3-M, pemeriksaan jentik berkala dan penyuluhan kepada keluarga atau masyarakat

PSN DBD adalah kegiatan memberantas telur, jentik dan kepompong nyamuk penular DBD (Aedes aegypti aegypti) ditempat-tempat perkembangbiakannya. Berdasarkan penelitian yang telah dilakukan oleh (Syarifah,2007)

PSN perlu di tingkatkan terutama pada musim penghujan dan pancaroba, karena meningkatnya curah hujan dapat meningkatkan tempat-tempat perkembangbiakan nyamuk penular $\mathrm{DBD}$, sehingga seringkali menimbulkan kejadian luar biasa (KLB) terutama pada saat musim penghujan.

Selain PSN 3M Plus, sejak Juni 2015 Kemenkes sudah mengenalkan program 1 rumah 1 Jumantik (juru pemantau jentik) untuk 
menurunkan angka kematian dan kesakitan akibat Demam Berdarah Dengue. Gerakan ini merupakan salah satu upaya preventif mencegah Demam Berdarah Dengue (DBD) dari mulai pintu masuk negara sampai ke pintu rumah.

Terjadinya KLB DBD di Indonesia berhubungan dengan berbagai faktor risiko, yaitu:

a. Lingkungan yang masih kondusif untuk terjadinya tempat perindukan nyamuk Aedes aegypti ;

b. Pemahaman masyarakat yang masih terbatas mengenai pentingnya pemberantasan sarang nyamuk (PSN) 3M Plus;

c. Perluasan daerah endemic akibat perubahan dan manipulasi lingkungan yang etrjadi karena urbanisasi dan pembangunan tempat pemukiman baru; serta

d. Meningkatnya mobilitas penduduk.

Pemberantasan terhadap jentik nyamuk Aedes aegypti yang dikenal dengan istilah PSN DBD dilakukan dengan cara: Fisik: cara ini dikenal dengan kegiatan 3-M yaitu menguras dan menyikat bak mandi, bak wc, dan lain-lain. Menutup tempat penampungan air rumah tangga (tempayan, drum, dan lain-lain). Mengubur, menyingkirkan atau memusnahkan barang-barang bekas (seperti kaleng, ban, dan lain-lain). Kimia: cara memberantas jentik Aedes aegypti dengan menggunakan insektisida pembasmi jentik (larvasida) ini antara lain dikenal dengan istilah larvasidasi. Larvasida yang biasa digunakan adalah granules (sandgranules). Dosis yang digunakan $10 \mathrm{gram}$ $( \pm 1$ sendok makan rata) untuk tiap100 liter air. Larvasidasi dengan temephos ini mempunyai efek residu 3 bulan. Serta biologi :cara ini dengan memelihara ikan pemakan jentik (ikan kepala timah, ikan gupi, ikan cupang dan lainlain). Dapat juga dengan menggunakan Bacillus thuringiensis.

Selain belum menguras dan menutup tempat-tempat penampungan air, banyak responden yang menempatkan tempat-tempat penampungan air diluar rumah. Perilaku ini juga memberikan peluang bagi nyamuk Aedes aegypti untuk bertelur. Keadaan rumah responden yang lembab dan kurang pencahayaan juga merupakan tempat yang potensial bagi nyamuk Aedes aegypti untuk berkembangbiak, karena nyamuk Aedes aegypti suka beristirahat dan berkembangbiak pada tempat yang gelap dan lembab. Perilaku responden yang suka menggantung pakaian didinding juga menjadi tempat yang disukai nyamuk Aedes aegypti untuk istirahat setelah menghisap darah manusia. Sebaiknya responden tidak menggantung pakaian di belakang pintu supaya tidak menjadi tempat nyamuk beristirahat. Selalu membuka jendela pada pagi hari agar cahaya dapat masuk kedalam rumah dan mengurangi kelembaban ruangan.

\section{Pengetahuan}

Hasil penelitian diketahui bahwa pada kelompok kasus yang memiliki pengetahuan baik sebanyak 2 oráng $(25,0 \%)$, sedangkan yang mempunyai pengetahun kurang baik sebanyak 22 orang $(75,5 \%)$. Pada kelompok kontrol yang memiliki pengetahuan baik sebanyak 57 orang $(62,5 \%)$, sedangkan yang mempunyai pengetahun kurang baik sebanyak 39 orang $(37,5 \%)$.

Hasil uji statistik dengan chi square diperoleh $p$-value $=0,003$ yang berarti bahwa ada hubungan kejadian DBD dengan pengetahuan, kemudian diperoleh $\mathrm{OR}=7,526$ yang berarti bahwa responden yang mempunyai pengetahun kurang baik mempuntyai risiko sebanyak 7,526 kali mengalami kejadian DBD dibandingkan dengan responden yang mempunyai pengetahun baik.

Keadaan ini sesuai dengan penelitian Ririh Y. dan Anny V (2005) di Surabaya yang menyebutkan bahwa terdapat hubungan yang bermakna antara kejadian DBD dengan tingkat pengetahuan responden.

Pengetahuan responden mengenai Demam Berdarah Dengue, vektor penyebabnya serta faktor yang mempengaruhi keberadaan jentik nyamuk Aedes aegypti sangat diperlukan untuk mencegah terjadinya penularan penyakit DBD serta menekan perkembangan dan pertumbuhan jentik nyamuk Aedes aegypti aegypti. Kurangnya pengetahuan dapat berpengaruh pada tindakan yang akan dilakukan, karena menurut Green (1980) yang dikutip dari Notoatmodjo (1993) bahwa pengetahuan merupakan salah satu faktor predisposisi untuk terjadinya perilaku.

Masyarakat diharapkan ikut berperan serta aktif dalam menjaga kebersihan lingkungannya bersikap proaktif dalam melakukan gerakan $3 \mathrm{M}$ plus. Sebaiknya 
petugas kesehatan terus meningkatkan penyuluhan dan penyampaian informasi tentang pencegahan dan penanggulangan DBD melalui media massa, media cetak maupun media elektronik. Serta selalu melakukan monitoring dan evaluasi petugas jumantik.

Hasil penelitian Rudi (2010) menyatakan responden yang berpengetahuan rendah tentang PSN DBD memiliki risiko terkena DBD 7,944 kali lebih besar dibandingkan dengan responden yang memiliki pengetahuan tinggi tentang PSN.

\section{KESIMPULAN}

Faktor yang berhubungan dengan DBD di wilayah kerja Puskesmas Ambarawa pada tahun 2017 adalah keberadaan jentik, letak kontainer, perilaku PSN, pengetahuan. Tidak ada hubungan antara jenis kontainer dengan kejadian DBD di wilayah kerja Puskesmas Ambarawa pada tahun 2017.

\section{DAFTAR PUSTAKA}

Achmadi, 2010, "Manajemen Demam Berdarah Berbasis Wilayah", Buletin Jendela Epidemiologi volume 2, Kementrian Kesehantan RI.

Depkes RI, 2004, Demam Berdarah Dengue, Www.Depkes.go.id, [tersedia Januari 2017, 15.45 ]

Dinas Kesehatan Provinsi Lampung, 2015, Profil Kesehatan Kabupaten Pringsewu, Lampung

Depkes RI. (1992.a). Petunjuk Teknis Pemberantasan Nyamuk Penular Penyakit Demam Berdarah Dengue . Jakarta : Dirjen PPM dan PLP.

Depkes RI. (1992.b). Petunjuk Teknis Pengamatan Penyakit Demam Berdarah Dengue. Jakarta : Dirjen PPM dan PLP.

Dinas Kesehatan Kota Surabaya. (2003). Laporan Tahunan Tahun 2003. Surabaya.

Depkes RI. (1996.a). Modul Latihan Kader Dalam Pemberantasan Sarang Nyamuk Demam Berdarah Dengue. Jakarta : Dirjen PPM dan PLP.

Depkes RI, 2014, Profi Keschatan Provinsi Lampung. Www.Depkes.go.id [tersedia Januari 2012, 15.30]

Depkes RI, 2015, Profil Kesehatan Kabupaten Pringsewu, Www.Depkes.Go.Id [tersedia Januari 2017, 15.22]
Depkes RI, 2004, "Prilaku Dan Siklus Hidup Nyamuk Aedes Aegypti", Buletin Harian (News Letter), Edisi Rabu 10 Maret 2004 , Departement Kesehatan RI, Jakarta.

Depkes RI, 2009, Penyelidikan Dan Penanggulangan Kejadian Luar Biasa (KLB) Penyakit Menular Dan Keracunan, Departement Kesehatan RI, Jakarta.

Depkes RI, 2016, Kendalikan DBD Dengan PSN $3 \mathrm{M}$ Plus, http://www.depkes.go.id/article/view/1602 0900002/kendalikan-dbd-dengan-psn-3mplus.html [tersedia 28 Juli 2017]

Gerakan 3M pencegah demam berdarah, 2012, http://elsabktaviasari20.blogspot.co.id/ [tersedia 28 Juli 2017]

Kemenkes RI, (2016), Menkes: Dibanding Fogging, PSN $3 M$ Plus Lebih Utama Cegah DBD, http://dinkes.inhukab.go.id/?p=3731 [tersedia 28 Juli 2017]

Kemenkes RI, (2016), Kendalikan DBD Dengan PSN $3 M$ Plus, http://dinkes. inhukab.go.id/?p=3731 [tersedia 28 Juli 2017]

Notoatmodjo S, 2010, Ilmu Prilaku Kesehatan, Rineka Cipta, Jakarta

Notoatmodjo S, 2005, Metodologi Penelitian Kesehatan, Edisi Revisi, Rineka Cipta, Jakarta.

Nur Purwoko Widodo, 2012, Faktor-Faktor Yang Berhubungan Dengan Kejadian DBD di Kota Mataram Provinsi Nusa Tenggara Barat, Tesis,

Nyamuk aedes dan pengendaliannya, 2010, http:/tipswarta.blogspot.co.id/2011/04/ma kalah-nyamuk-aedes-danpengendaliannya.html [tersedia 28 Juli 2017]

Santhi N, Darmadi I, Aryasih IGAM. (2014). Jurnal Kesehatan Lingkungan Vol. 4 no 2 [tersedia 27 juli 2017]

Sitio, A, 2008, Hubungan Prilaku Tentang PSN Dan Kebiasaan Keluarga Dengan Kejadian DBD Di Kecamatan Medan Perjuangan Kota Medan, Tesis, Universitas Diponogoro.

Soegijanto, Soegeng, 2006 Demam Berdarah Dengue Edisi.2, Airlangga University Press, 272 halaman. 
Tanaya W, 2013, Parasitologi nyamuk aedes egeypti

http://wisnutanaya2.blogspot.co.id/2013/07 /aedes-aegypti.html [tersedia 28 Juli 2017]

WHO, 2011, Situation Of Dengue/Dengue Haemmorrhagic Fever In The South- East Asia Region, Http:// Www.Searo. Who.Int/En/Section 10/Sectio n 32_1103. Htm, [tersedia Januari 2017, 19.15 ].

WHO, 2009, Departemen Kesehatan Republik Indonesia, Www. Depkes. Go. Id /773Kasus-Demam-Berdarah-Dengue-

Diindonesia.Html. [ tersedia 2 Januari 2017, 19.25].
Yanuaryani, 2013. Rumah dan Kelembaban, https://udararuang.wordpress.com/ tersedia 27 juli 2017]

Yotopranoto, S., Sri Subekti, Rosmanida, Sulaiman. (1998). Dinamika Populasi Vektor pada Lokasi dengan K asus Demam Berdarah Dengue yang Tinggi di Kotamadya Surabaya. Majalah Kedokteran Tropis Indonesia.Vol 9: No. 1 -2. 